\title{
Preparation and characterization of magnetic chlorochromate hybrid nanomaterials with triphenylphosphine surface-modified iron oxide nanoparticles
}

\author{
Ali Maleki • Rahmatollah Rahimi • Saied Maleki
}

Received: 26 July 2014/ Accepted: 3 October 2014/Published online: 31 October 2014

(C) The Author(s) 2014. This article is published with open access at Springerlink.com

\begin{abstract}
In this paper, a new magnetic hybrid nanomaterial $\left(\mathrm{Fe}_{3} \mathrm{O}_{4} @ \mathrm{SiO}_{2} @ \mathrm{PPh}_{3} @\left[\mathrm{CrO}_{3} \mathrm{Cl}\right]\right)$ was reported for the first time. The magnetic $\mathrm{Fe}_{3} \mathrm{O}_{4}$ nanoparticles were prepared by hydrothermal process and coated with a silica shell. Then, the core-shell nanoparticles $\left(\mathrm{Fe}_{3} \mathrm{O}_{4} @ \mathrm{SiO}_{2}\right)$ were functionalized by 3-chloropropyl trimethoxysilane plus triphenylphosphine for forming the cationic part of support. Finally, anionic part of the $\mathrm{Cr}(\mathrm{VI})$ catalyst $\left(\left[\mathrm{CrO}_{3} \mathrm{Cl}\right]^{-}\right)$was immobilized on the magnetic support $\left(\mathrm{Fe}_{3} \mathrm{O}_{4} @ \mathrm{SiO}_{2} @ \mathrm{PPh}_{3}\right)$. The structural characteristics of the product were determined using elemental analysis, X-ray fluorescence (XRF), X-ray diffraction (XRD), Fourier transform infrared (FT-IR) and solid state UV-Vis. The particle size and morphology were identified by scanning electron microscope (SEM), transmission electron microscopy (TEM) and XRD. A vibrant sample was employed to determine the magnetic properties of the prepared samples.
\end{abstract}

Keywords Magnetic nanoparticles $\cdot \mathrm{Fe}_{3} \mathrm{O}_{4}$.

Heterogeneous catalysts $\cdot$ Chlorochromate $\cdot$ Nanomaterial

\section{Background}

Chromium(VI) is the most commonly useful compound among oxidizing agents based on higher valent transition metal-oxo derivatives; similarly reagents were derived from ruthenium, osmium, iron, manganese, molybdenum and vanadium. There is excessive interest in the formation

A. Maleki ( $₫) \cdot$ R. Rahimi · S. Maleki Catalysts and Organic Synthesis Research Laboratory,

Department of Chemistry, Iran University of Science and

Technology, 16846-13114 Tehran, Iran

e-mail: maleki@iust.ac.ir of new chromium(VI) reagents for the effective and selective oxidation of organic substrates, especially alcohols under mild conditions [1]. In recent years, Ghammamy achieved remarkable development in the application of the new oxidizing agent. Quaternary ions such as phosphonium are often used as phase transfer catalysts. This could make triphenylpropylphosphonium chlorochromate (VI), $\mathrm{PrPh}_{3} \mathrm{P}\left[\mathrm{CrO}_{3} \mathrm{Cl}\right]$, PTriPPCC a more effective and strong oxidizing agent. This compound is used for quantitative oxidation of many organic substrates [2].

Simple separation and recycling of the catalyst is an essential step in catalytic technology and often affects the overall process economy. In spite of this, the homogeneous catalysts are extremely efficient, but the separation and reuse of the catalyst are very hard. As a result, making of efficient heterogeneous catalysts is completely necessary and therefore immobilization of homogeneous catalysts has attracted a lot of attention. A possible method is immobilizing catalytically active species on the surface of magnetic particles, which can be separated and reused from the reaction system through an appropriate magnetic field [3].

Among the various nanostructure materials, metal oxide nanoparticles are the remarkable class of materials. Their particular properties such as optical, magnetic, and electrical cause vast range of high tech usages of them [4-7]. Magnetite $\left(\mathrm{Fe}_{3} \mathrm{O}_{4}\right)$ nanoparticle has attracted great attention in recent years not only because of its unmatched size and morphology-related physical and chemical properties but also for its biocompatibility and significant magnetic properties. It has a cubic inverse spinel structure with oxygen, forming FCC closed packing and $\mathrm{Fe}$ cations occupying interstitial tetrahedral and octahedral sites. The electrons can hop between $\mathrm{Fe}^{2+}$ and $\mathrm{Fe}^{3+}$ ions in the octahedral sites at room temperature causing $\mathrm{Fe}_{3} \mathrm{O}_{4}$ to be a main class of half-metallic materials [8]. They show 
superparamagnetism, which means that the particles are attracted to an external magnetic field, but maintain no remaining magnetization after elimination of the magnetic field. Consequently, suspended magnetite nanoparticles can be separated quickly from solution by an external magnet without agglomeration after removing external magnet. In general, to prevent direct contact between magnetite nanoparticles and prepare a chemically inert surface for modification of magnetite nanoparticles, coating of the surface with silica shell is necessary. Silica surface easily functionalized with various organic groups for appropriate purposes such as applications as adsorbent, catalysis support, enzyme immobilization, and so on [9].

In the present work, we have planned a style for creating a magnetically recoverable nanocatalyst in which chlorochromate $\left[\mathrm{CrO}_{3} \mathrm{Cl}\right]^{-}$was immobilized on triphenylphosphine-functionalized silica-coated iron oxide nanoparticles $\left(\mathrm{Fe}_{3} \mathrm{O}_{4} @ \mathrm{SiO}_{2} @ \mathrm{PPh}_{3} @\left[\mathrm{CrO}_{3} \mathrm{Cl}\right]\right)$. Because of the presence of magnetite core, the prepared hybrid nanomaterials have superparamagnetic properties. It can be tested in different fields such as catalytic oxidation of olefins, alcohols, and multicomponent reactions where it can act as magnetically retrievable catalyst.

\section{Experimental}

\section{Materials and instrumentation}

All chemicals were purchased from Merck, Fluka, and Aldrich chemical companies and used without further purification.

Chemical analyzes of the samples were produced with Philips-PW1480 X-ray fluorescence (XRF). The crystalline phase of the nanoparticles was characterized by means of $\mathrm{X}$-ray diffraction (XRD) measurements using $\mathrm{Cu} \mathrm{K}_{\alpha}$ radiation $(\lambda=1.54 \AA)$ on a Philips-PW1800 diffractometer in the $2 \theta$ range of $4-90^{\circ}$. Fourier transform infrared (FT-IR) spectra was recorded using a Perkin-Elmer Spectrum RXI FT-IR spectrometer, using pellets of the nanomaterials diluted with $\mathrm{KBr}$. Solid state UV-Vis was registered by Jasco spectrometer. Scanning electron micrograph (SEM) studies of the samples were carried out with a Zeiss-DSM 960A microscope with an attached camera. Transmission electron microscopy (TEM) analysis was performed using a Zeiss EM 900 electron microscope operating at $80 \mathrm{kV}$. Magnetic susceptibility measurements were performed with a vibrating sample magnetometer (BHV-55, Riken, Japan) in the magnetic field range of $-10,000$ to $+10,000$ Oe at room temperature.
Preparations of spherical $\mathrm{Fe}_{3} \mathrm{O}_{4}$ particles (MNPs)

With an improved strategy, the magnetite nanoparticles were prepared [10, 11]. Normally, $\mathrm{FeCl}_{3} \bullet 6 \mathrm{H}_{2} \mathrm{O}(2.7 \mathrm{~g})$ dissolved in ethylene glycol $(80 \mathrm{~mL})$ to form a transparent solution, followed by the addition of $\mathrm{NaAc}(14.4 \mathrm{~g})$ as a base. The mixture was stirred vigorously for $30 \mathrm{~min}$ and then transferred into a $100 \mathrm{~mL}$ Teflon-lined autoclave and heated at $200{ }^{\circ} \mathrm{C}$ for $10 \mathrm{~h}$. Next, the reaction system was allowed to cool to room temperature. The as-synthesized black products were washed with ethanol and deionized water thoroughly.

Preparation of silica-coated magnetite nanoparticles $\left(\mathrm{Fe}_{3} \mathrm{O}_{4} @ \mathrm{SiO}_{2}\right)(\mathrm{SCMNPs})$

Silica-coated magnetite nanoparticles, $\mathrm{Fe}_{3} \mathrm{O}_{4} @ \mathrm{SiO}_{2}$, were prepared according to the modified method reported by Stober [12-19]. Typically, the former $\mathrm{Fe}_{3} \mathrm{O}_{4}$ particles $(1.5 \mathrm{~g})$ were dispersed in $200 \mathrm{~mL}$ water-ethanol $(1: 4, \mathrm{v} / \mathrm{v})$ solution, followed by the addition of $5 \mathrm{~mL}$ ammonia solution $(25 \mathrm{wt} \%)$ and $2.0 \mathrm{~mL}$ tetraethyl orthosilicate TEOS consecutively. The mixture was reacted for $24 \mathrm{~h}$ at the room temperature under continuous stirring. Next, the product was collected by external magnet and then washed with deionized water. Finally, the resulting silica-coated magnetic nanoparticles were dried under vacuum at $60{ }^{\circ} \mathrm{C}$ for further use.

Functionalizing of silica-coated magnetite nanoparticles $\mathrm{Fe}_{3} \mathrm{O}_{4} @ \mathrm{SiO}_{2}$ (SCMNPs) with triphenylphosphine (PCPTSCMNPs)

First, in the manner, the resulting silica-coated magnetic nanoparticles $(1 \mathrm{~g})$ were dispersed in dry toluene $(80 \mathrm{~mL})$ by ultrasonic treatment for $40 \mathrm{~min}[12,16]$. Then, 3-chloropropyl-trimethoxysilane (5 g) and triphenylphosphine $(8 \mathrm{~g})$ were added in dispersed nanoparticles, and the mixture was refluxed at for $48 \mathrm{~h}$ at $110{ }^{\circ} \mathrm{C}$ under nitrogen protection. After the surface modification step, the solid product was cooled, isolated with a magnet, washed twice with deionized water $(100 \mathrm{~mL})$ and ethanol $(100 \mathrm{~mL})$, then dried in vacuum at $60{ }^{\circ} \mathrm{C}[15]$.

Synthesis of chlorochromate (VI), $\left[\mathrm{CrO}_{3} \mathrm{Cl}\right]^{-}$

To a solution of $\mathrm{CrO}_{3}(0.01 \mathrm{~mol} / 100 \mathrm{~mL})$ in $\mathrm{H}_{2} \mathrm{O}$ was added a solution of $(0.01 \mathrm{~mol})$ in $\mathrm{HCl}$ under stirring at room temperature until an orange solution was formed [2]. 
Synthesis of $\mathrm{Fe}_{3} \mathrm{O}_{4} @ \mathrm{SiO}_{2} @ \mathrm{PPh}_{3} @\left[\mathrm{CrO}_{3} \mathrm{Cl}\right]$ (CCr-PCPTSCMNPs)

$\mathrm{Fe}_{3} \mathrm{O}_{4} @ \mathrm{SiO}_{2} @ \mathrm{PPh}_{3}(1 \mathrm{~g})$ was dispersed in $100 \mathrm{ml}$ of distilled water, then $\left[\mathrm{CrO}_{3} \mathrm{Cl}\right]^{-}(0.1 \mathrm{mmol})$ was added. The resulting mixture was left for stirring for $24 \mathrm{~h}$ at room temperature. Next, the resulting $\mathrm{Fe}_{3} \mathrm{O}_{4} @ \mathrm{SiO}_{2} @ \mathrm{PPh}_{3} @$ $\left[\mathrm{CrO}_{3} \mathrm{Cl}\right]$ was washed with water and diethyl ether thoroughly and dried under vacuum at $60{ }^{\circ} \mathrm{C}$ [9].

\section{Results and discussion}

Preparation of magnetite chlorochromate nanomaterials

The sequence of steps in the immobilization of chlorochromate in the magnetite nanoparticles is illustrated in Fig. 1. In the first step, hydrothermal method was applied to the synthesis of $\mathrm{Fe}_{3} \mathrm{O}_{4}$ magnetic nanoparticles. Second, the external surface of MNPs was coated with silica shell to create SCMNPs. This silica coating protects the magnetic nanoparticles from possible decomposition induced by the surrounding environment and prevents further aggregation. In addition, the silica surface can be functionalized using a variety of known surface modifiers. The action of silanol groups of SCMNPs with triphenylphosphonium (3-chloropropyl) trimethoxysilane generated PCPTSCMNPs. The next step involves reaction of PCPTSCMNPs groups with chlorochromate to yield the magnetite chlorochromate nanomaterials CCr-PCPTSCMNPs. In this step, phosphonium groups give positively charged cations which bounds electrostatically to the chlorochromate. The excess of chlorochromate was removed by washing the resulted materials with water. The attached chlorochromate anions are stable on the surface of modified magnetite and cannot be leached to an aqueous solution [9].

Characterization of the prepared magnetitechlorochromate nanomaterials

To demonstrate the surface modification of the magnetite nanoparticles and preparation of magnetite-chlorochromate nanomaterials, the FT-IR spectra of the ready MNPS, SCMNPs, PCPTSCMNPs, and CCr-PCPTSCMNPs are illustrated in Fig. 2.

As shown in Fig. 2a, $\mathrm{Fe}_{3} \mathrm{O}_{4}$ typical bands centered at 586 and $640 \mathrm{~cm}^{-1}$, which related to the $\mathrm{Fe}-\mathrm{O}$ stretches. The surfaces of $\mathrm{Fe}_{3} \mathrm{O}_{4}$ powder contain surface hydroxyl functional groups $(\mathrm{Fe}-\mathrm{OH})$ whose characteristic IR peak was at 3,500 $\mathrm{cm}^{-1}$ in FT-IR plot shown in Fig. 2a [12-14, 20, 21]. After the coating of $\mathrm{Fe}_{3} \mathrm{O}_{4} @ \mathrm{SiO}_{2}$ core-shells, the silane framework on the surface of the MNPs was confirmed by the FT-IR bands at 1,105, 1,039 and $994 \mathrm{~cm}^{-1}$ assigned to the $\mathrm{Si}-\mathrm{O}-\mathrm{H}$ and $\mathrm{Si}-\mathrm{O}-\mathrm{Si}$ groups [18] (Fig. 2b). These results indicate that $\mathrm{Fe}_{3} \mathrm{O}_{4} @ \mathrm{SiO}_{2}$ is formed $[12,15$, 16]. The presence of anchored propyl and triphenylphosphine groups was confirmed by stretching vibrations appeared at about $2,935,2,870 \mathrm{~cm}^{-1}(\mathrm{C}-\mathrm{H}$ stretching vibrations) in the FT-IR spectrum of PCPTSCMNPs (Fig. 2c) $[9,20]$. The presence of absorption bands 430,

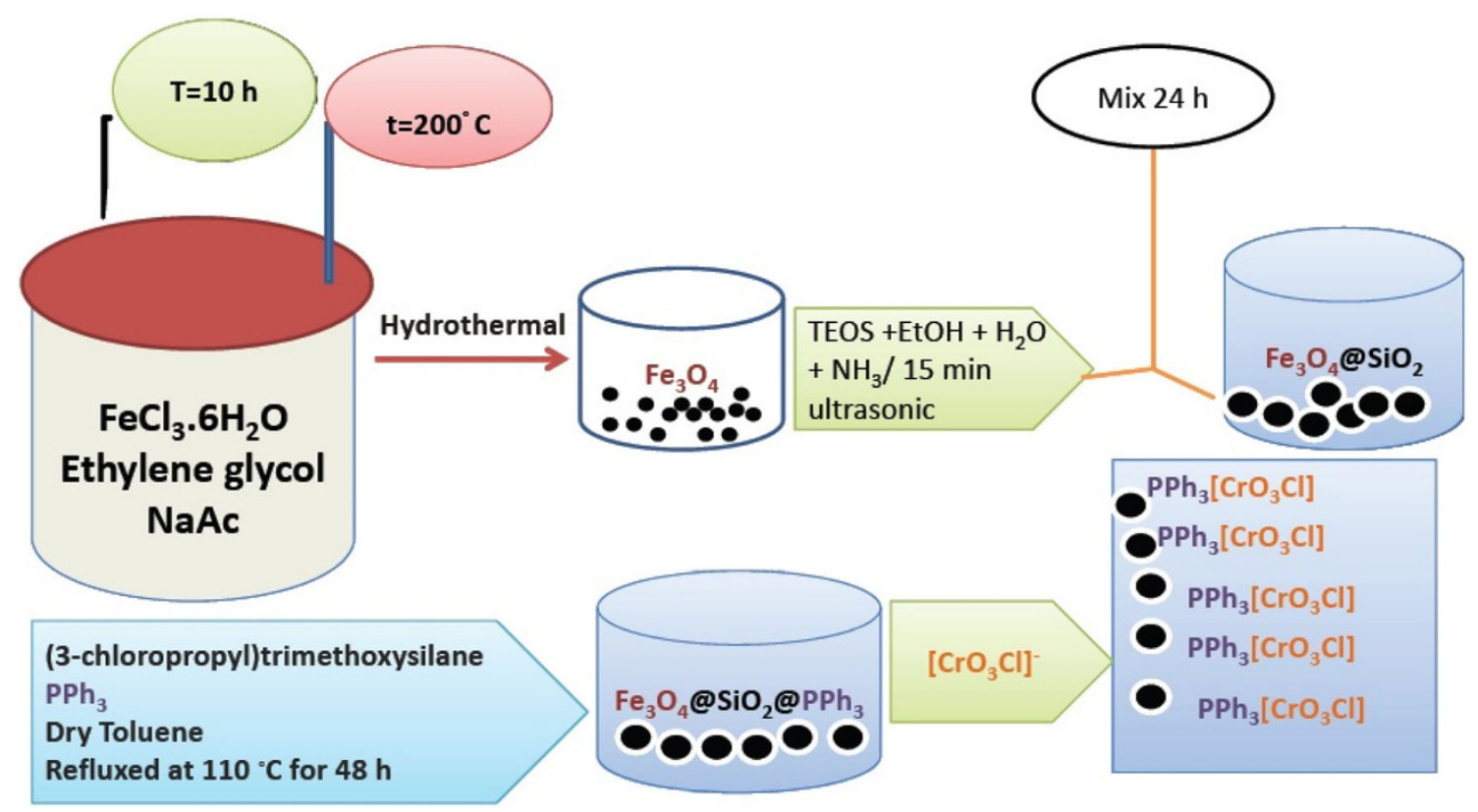

Fig. 1 Schematic illustration for the preparation of $\mathrm{Fe}_{3} \mathrm{O}_{4} @ \mathrm{SiO}_{2} @ \mathrm{PPh}_{3} @\left[\mathrm{CrO}_{3} \mathrm{Cl}\right]$ 

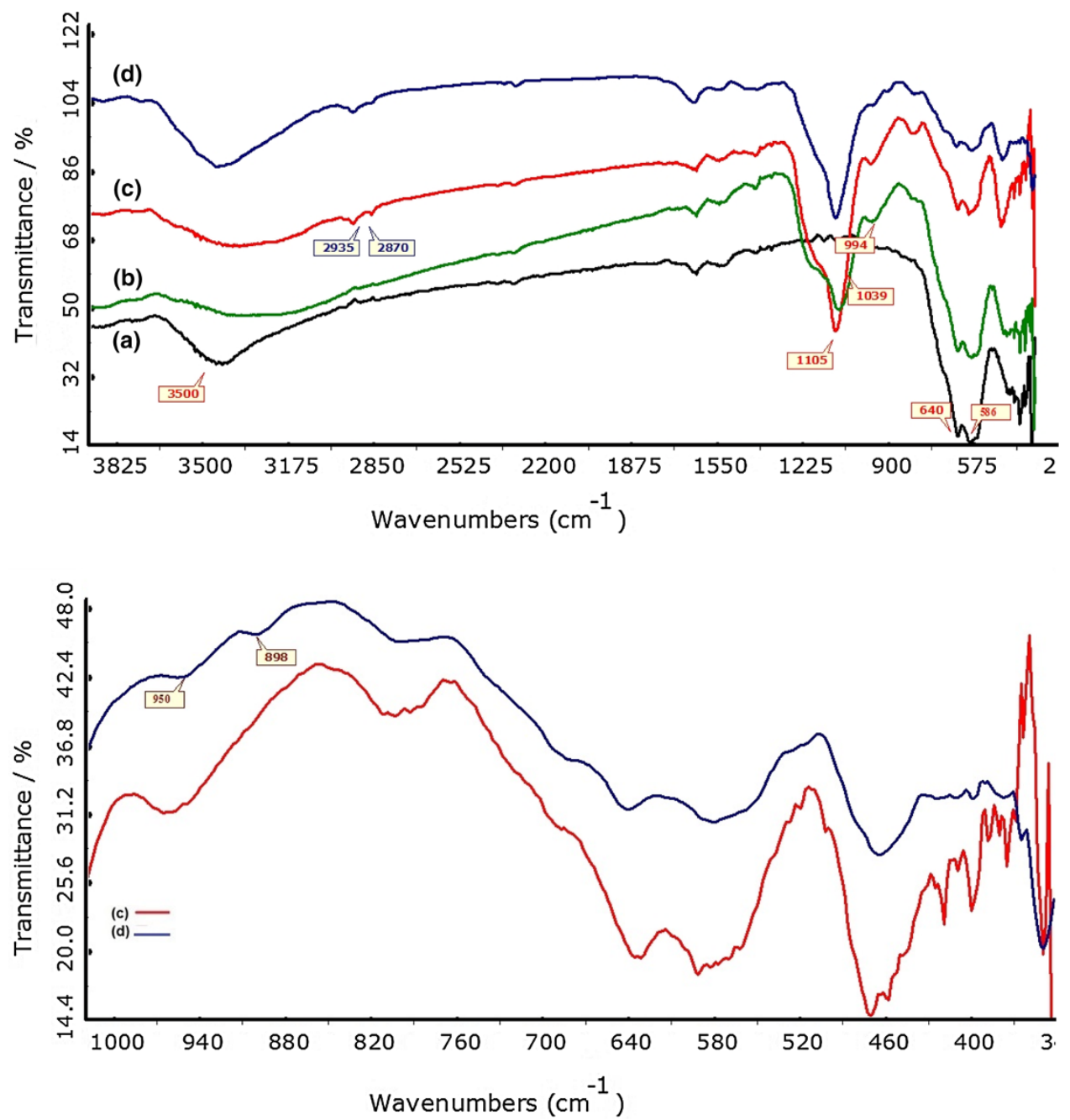

Fig. 2 FT-IR spectra of a $\mathrm{Fe}_{3} \mathrm{O}_{4}, \mathbf{b} \mathrm{Fe}_{3} \mathrm{O}_{4} @ \mathrm{SiO}_{2}, \mathbf{c} \mathrm{Fe}_{3} \mathrm{O}_{4} @ \mathrm{SiO}_{2} @ \mathrm{PPh}_{3}$ and $\mathbf{d} \mathrm{Fe}_{3} \mathrm{O}_{4} @ \mathrm{SiO}_{2} @ \mathrm{PPh}_{3} @\left[\mathrm{CrO}_{3} \mathrm{Cl}\right]$

Table 1 Results of chemical analysis of XRF of the $\mathrm{Fe}_{3} \mathrm{O}_{4} @ \mathrm{SiO}_{2} @ \mathrm{PPh}_{3} @\left[\mathrm{CrO}_{3} \mathrm{Cl}\right]$

\begin{tabular}{lllllll}
\hline Element & $\mathrm{Fe}$ & $\mathrm{Si}$ & $\mathrm{O}$ & $\mathrm{Cr}$ & $\mathrm{P}$ & LOI \\
\hline$(\%)$ & 24.46 & 27.93 & 33.84 & 1.04 & 1.17 & 11.56 \\
\hline
\end{tabular}

770, 805, 895, 905 ( $\left.v_{\text {asymmetric }} \mathrm{Cr}=\mathrm{O}\left(\mathrm{A}_{1}\right)\right), 940\left(\mathrm{v}_{\text {symmetric }}\right.$ $\mathrm{Cr}=\mathrm{O}(\mathrm{E}))$ approbated the immobilization of chlorochromate (Fig. 2d) [1].

The elemental analysis (XRF) of the $\mathrm{Fe}_{3} \mathrm{O}_{4} @ \mathrm{SiO}_{2} @$ $\mathrm{PPh}_{3} @\left[\mathrm{CrO}_{3} \mathrm{Cl}\right]$ is shown in Table 1 . As can be seen in this Table, the quantity of Chromium is approximately $1.04 \%$, which confirms the immobilization amount of $\left[\mathrm{CrO}_{3} \mathrm{Cl}\right]^{-}$ which is equal to $0.02 \mathrm{~mol} / 100 \mathrm{~g}$. Loss on ignition (LOI) shows the quantity of organic matter in $\mathrm{Fe}_{3} \mathrm{O}_{4} @ \mathrm{SiO}_{2} @ \mathrm{PPh}_{3} @\left[\mathrm{CrO}_{3} \mathrm{Cl}\right]$.

Figure 3 shows the XRD spectrum of the magnetite chlorochromate nanoparticles. The XRD data show the diffraction peaks at $2 \theta=29.9765^{\circ}(220), 35.1295^{\circ}(311)$, $42.8283^{\circ}(400), 56.9694^{\circ}(511)$ and $62.56522^{\circ}$ (440) for sample. The reflection peak positions and relative intensities of MNPs are well in agreement with the XRD patterns of MNPs in the literature (JCPDS Card No. 19-0629). The results indicate that the shape of the MNPs is inverse spinel $\mathrm{Fe}_{3} \mathrm{O}_{4}$ with a face-centered cubic (FCC) structure, suggesting that the sample has a cubic crystal system. Moreover, no characteristic peaks of impurities were observed in the XRD spectrum [20, 22-24]. This indicates that chlorochromate species well dispersed on the surface of PCPTSCMNPs and there is no crystalline phase of chlorochromate in the resulted nanomaterials. The $\mathrm{D}$ values calculated from the XRD spectrum were indexed to the inverse cubic spinel phase of $\mathrm{Fe}_{3} \mathrm{O}_{4}$. From the width of the peak at $2 \theta=35.1295^{\circ}(311)$, the crystallite size of the $\mathrm{Fe}_{3} \mathrm{O}_{4} @ \mathrm{SiO}_{2} @ \mathrm{PPh}_{3} @\left[\mathrm{CrO}_{3} \mathrm{Cl}\right]$ nanoparticle is calculated to be $16.3 \mathrm{~nm}$ using Scherrer's equation: $D=0.89 \lambda /(\beta$ $\cos \theta$ ) where $D$ is the particle size, $\lambda$ is the X-ray 
Fig. 3 XRD pattern of $\mathrm{Fe}_{3} \mathrm{O}_{4} @ \mathrm{SiO}_{2} @ \mathrm{PPh}_{3} @\left[\mathrm{CrO}_{3} \mathrm{Cl}\right]$

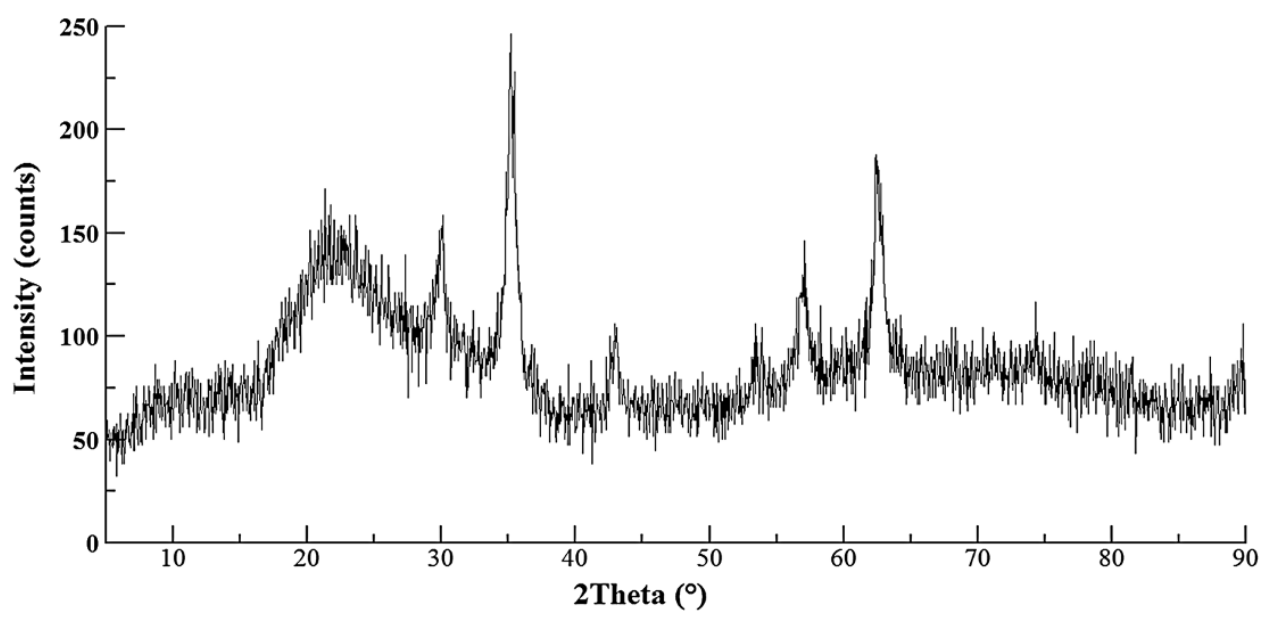

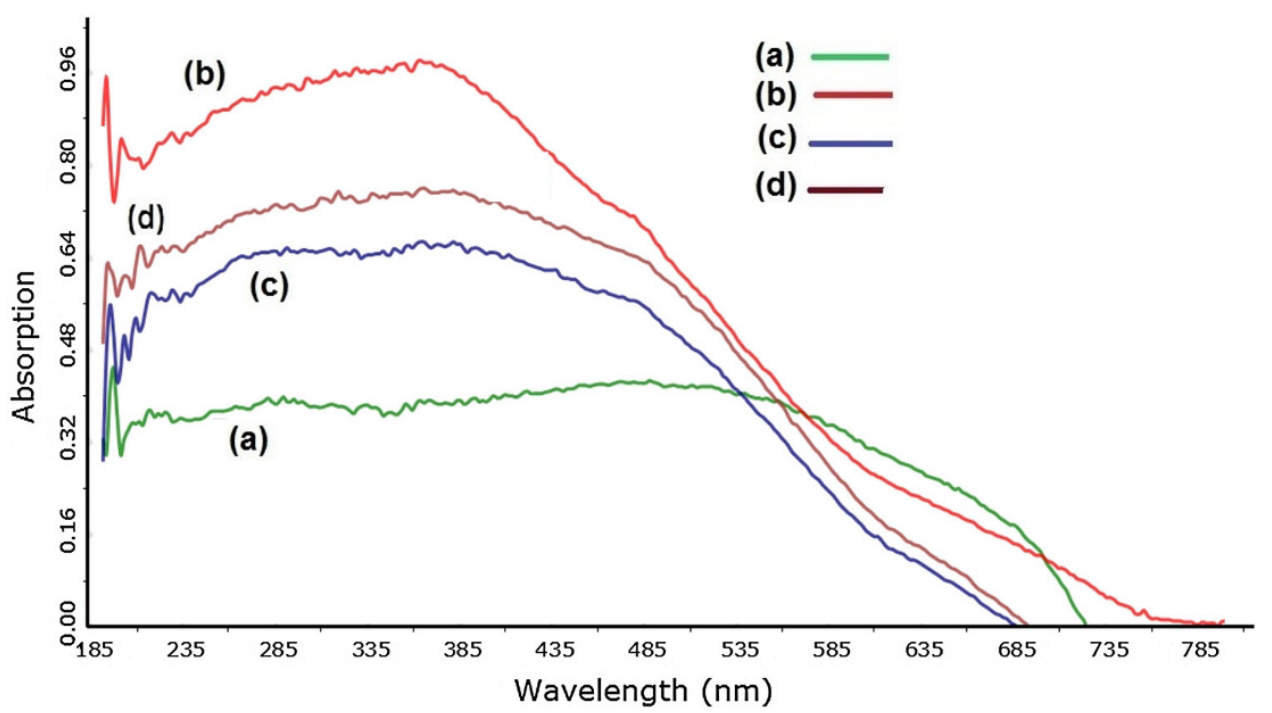

Fig. 4 Solid state UV-Vis spectra of a $\mathrm{Fe}_{3} \mathrm{O}_{4}$, b $\mathrm{Fe}_{3} \mathrm{O}_{4} @ \mathrm{SiO}_{2}, \mathbf{c} \mathrm{Fe}_{3} \mathrm{O}_{4} @ \mathrm{SiO}_{2} @ \mathrm{PPh}_{3}$ and $\mathbf{d} \mathrm{Fe}_{3} \mathrm{O}_{4} @ \mathrm{SiO}_{2} @ \mathrm{PPh}_{3} @\left[\mathrm{CrO} \mathrm{Cl}_{3}\right]$

wavelength (nm), $\theta$ is Bragg's angle; $\beta$ is the excess line broadening (radiant) [4, 25].

Figure 4 shows the absorption spectra of samples in the solid state. It is clear that the pure $\mathrm{Fe}_{3} \mathrm{O}_{4}$ absorbs light with wavelengths mainly below $762 \mathrm{~nm}$ (Fig. 4a). (In comparison with the optical absorption of $\mathrm{Fe}_{3} \mathrm{O}_{4}$, the absorption edge toward shorter wavelengths (blue shift) and increasing intensity in $<502 \mathrm{~nm}$ was observed in the absorption spectra of $\mathrm{Fe}_{3} \mathrm{O}_{4} @ \mathrm{SiO}_{2}$ (Fig. 4b). $\mathrm{Fe}_{3} \mathrm{O}_{4} @ \mathrm{SiO}_{2}$ and $\mathrm{Fe}_{3} \mathrm{O}_{4} @ \mathrm{SiO}_{2}$ with triphenylphosphine showed a red shift and decreasing in intensity (Fig. 4c). The $\mathrm{Fe}_{3} \mathrm{O}_{4} @ \mathrm{SiO}_{2} @$ $\mathrm{PPh}_{3} @\left[\mathrm{CrO}_{3} \mathrm{Cl}\right]$ showed a little blue shift with growth intensity (Fig. 4d).

Figure 5a shows the SEM images of the primary $\mathrm{Fe}_{3} \mathrm{O}_{4}$. The SEM images illustrate that the created $\mathrm{Fe}_{3} \mathrm{O}_{4}$ are spherical nanoparticles with an average grain size $16 \mathrm{~nm}$. Aggregation gives rise to enhancing the size of observed nanoparticles as observed in the SEM image. Figure 4b, c shows that iron oxide nanoparticles have core-shell mode and a spherical morphology. Figure 5d-f indicates images of obtaining $\mathrm{Fe}_{3} \mathrm{O}_{4} @ \mathrm{SiO}_{2} @ \mathrm{PPh}_{3} @\left[\mathrm{CrO}_{3} \mathrm{Cl}\right]$.

The TEM images shown in Fig. 6 demonstrated that the silica-magnetite compound made as supports of the catalyst had good spherical morphologies.

The magnetization measurements of $\mathrm{Fe}_{3} \mathrm{O}_{4}, \mathrm{Fe}_{3} \mathrm{O}_{4} @$ $\mathrm{SiO}_{2}$, and $\mathrm{Fe}_{3} \mathrm{O}_{4} @ \mathrm{SiO}_{2} @ \mathrm{PPh}_{3} @\left[\mathrm{CrO}_{3} \mathrm{Cl}\right]$ nanoparticles were performed by a vibrating sample magnetometer at room temperature (Fig. 7). Figure 7 indicates the schemes of the magnetization ' $M$ ' versus applied field ' $\mathrm{H}$ ' (between $-10,000$ and $+10,000 \mathrm{Oe})$ of these prepared $\mathrm{Fe}_{3} \mathrm{O}_{4}$, $\mathrm{Fe}_{3} \mathrm{O}_{4} @ \mathrm{SiO}_{2}$, and $\mathrm{Fe}_{3} \mathrm{O}_{4} @ \mathrm{SiO}_{2} @ \mathrm{PPh}_{3} @\left[\mathrm{CrO}_{3} \mathrm{Cl}\right]$ samples. As can be seen in Fig. 7, the values of the saturation magnetization were $53 \mathrm{emu} / \mathrm{g}$ for $\mathrm{Fe}_{3} \mathrm{O}_{4}$ nanoparticles, $37 \mathrm{emu} / \mathrm{g}$ for $\mathrm{Fe}_{3} \mathrm{O}_{4} @ \mathrm{SiO}_{2}$, and $25.4 \mathrm{emu} / \mathrm{g}$ for 

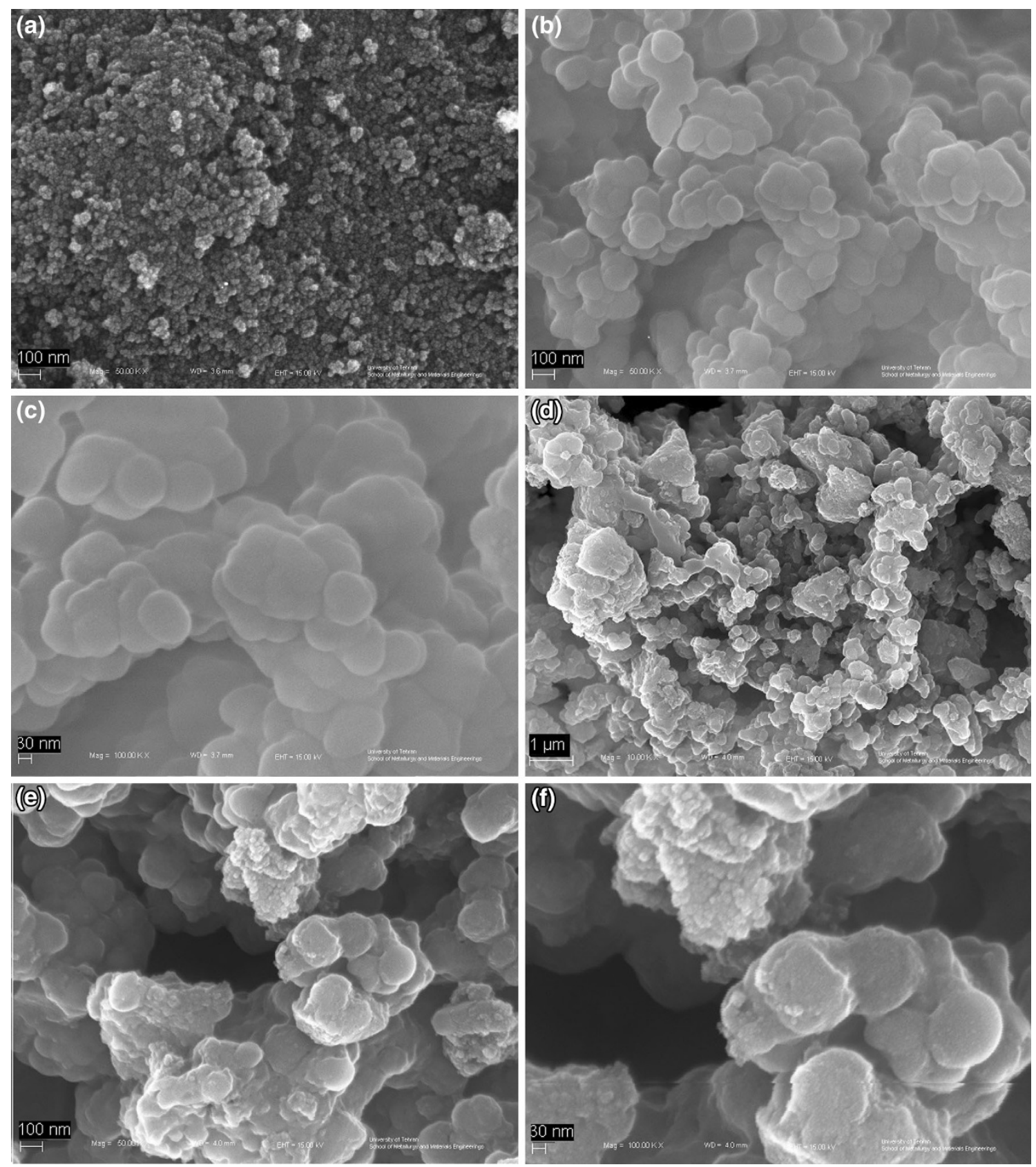

Fig. 5 Images of $\mathrm{SEMs}$ a $\mathrm{Fe}_{3} \mathrm{O}_{4}, \mathbf{b}, \mathbf{c} \mathrm{Fe}_{3} \mathrm{O}_{4} @ \mathrm{SiO}_{2}$, d, e, f Fe $\mathrm{O}_{4} @ \mathrm{SiO}_{2} @ \mathrm{PPh}_{3} @\left[\mathrm{CrO}_{3} \mathrm{Cl}\right]$

$\mathrm{Fe}_{3} \mathrm{O}_{4} @ \mathrm{SiO}_{2} @ \mathrm{PPh}_{3} @\left[\mathrm{CrO}_{3} \mathrm{Cl}\right]$, respectively. The reduction, nearly $25 \mathrm{emu} / \mathrm{g}$ of the saturation magnetization, proposes the presence of some $\mathrm{SiO}_{2} @ \mathrm{PPh}_{3} @\left[\mathrm{CrO}_{3} \mathrm{Cl}\right]$ on the surface of the magnetic supports.

\section{Conclusion}

This paper has explained the synthesis of magnetic $\left(\mathrm{Fe}_{3} \mathrm{O}_{4} @ \mathrm{SiO}_{2} @ \mathrm{PPh}_{3} @\left[\mathrm{CrO}_{3} \mathrm{Cl}\right]\right)$ by reacting triphenylphosphine-modified silica-coated magnetite nanoparticles with chlorochromate anion. In sum, the electrostatic interaction between the cationic iron oxide nanoparticles with triphenylphosphine-modified silica-coated magnetite nanoparticles, and the chlorochromate anion, resulted in immobilization of chlorochromate on the surface of modified $\mathrm{Fe}_{3} \mathrm{O}_{4} @ \mathrm{SiO}_{2} @ \mathrm{PPh}_{3}$ and preparation of magnetite chlorochromate hybrid nanomaterials $\left(\mathrm{Fe}_{3} \mathrm{O}_{4} @ \mathrm{SiO}_{2} @\right.$ $\left.\mathrm{PPh}_{3} @\left[\mathrm{CrO}_{3} \mathrm{Cl}\right]\right)$. The physicochemical specifications demonstrated the almost similar size of about $16 \mathrm{~nm}$ and spherical morphologies of synthesized superparamagnetic nanoparticles. In the future, we decided to test the power of 
(a)

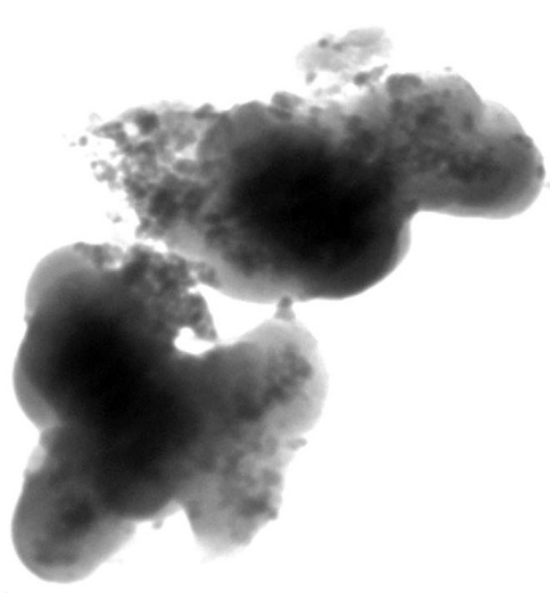

$100 \mathrm{~nm}$

(b)
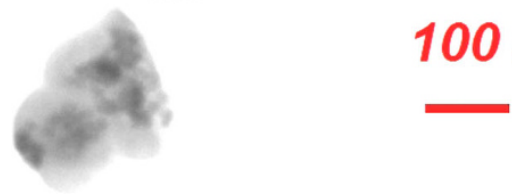

\section{$25 n m$}

Fig. 6 Magnetization curves of a $\mathrm{Fe}_{3} \mathrm{O}_{4}, \mathbf{b} \mathrm{Fe}_{3} \mathrm{O}_{4} @ \mathrm{SiO}_{2} @ \mathrm{PPh}_{3} @\left[\mathrm{CrO}_{3} \mathrm{Cl}\right]$

Fig. 7 Applied magnetic field (Oe)

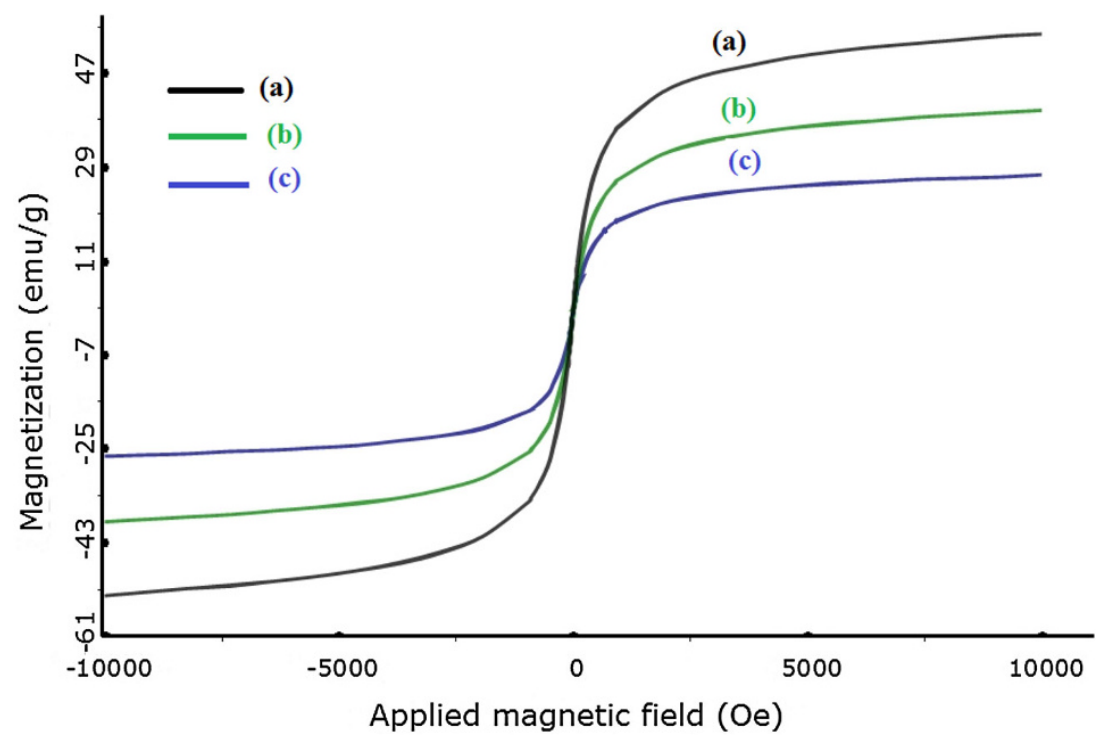

catalyst in oxidation of organic matter, desulfurization of fuel and multicomponent reactions.

Acknowledgments The authors gratefully acknowledge financial support from the Research Council of the Iran University of Science and Technology (IUST).

Open Access This article is distributed under the terms of the Creative Commons Attribution License which permits any use, distribution, and reproduction in any medium, provided the original author(s) and the source are credited.

\section{References}

1. Ghammamy, S., Baghy, M.R., Mirrahimi, M., Vaira, M.D., Javanshir, Z., Mehrani, K., Maleki, S.: Synthesis, characterization, $\mathrm{X}$-ray structural analysis and study of oxidative properties of a chlorochromate(VI) complex with benzyltriphenylphosphonium cation. Transit. Met. Chem. 34, 565-570 (2009)

2. Ghammamy, S., Baghy, M.R., Tak, W.W., Mehrani, K., Maleki, S.: Synthesis, characterization, X-ray structural analysis and study of oxidative properties of propyltriphenylphosphonium bromochromate. Transit. Met. Chem. 32, 257-261 (2007) 
3. Zhang, Z., Zhang, F., Zhu, Q., Zhao, W., Ma, B., Ding, Y.: Magnetically separable polyoxometalate catalyst for the oxidation of dibenzothiophene with $\mathrm{H}_{2} \mathrm{O}_{2}$. J. Colloid Interface Sci. 360, 189-194 (2011)

4. Mohammadi, A., Barikani, M., Barmar, M.: Effect of surface modification of $\mathrm{Fe}_{3} \mathrm{O}_{4}$ nanoparticles on thermal and mechanical properties of magnetic polyurethane elastomer nanocomposites. J. Mater. Sci. 48, 7493-7502 (2013)

5. Guo, J., Jiang, B., Zhang, X., Zhou, X., Hou, W.: $\mathrm{Fe}_{2.25} \mathrm{~W}_{0.75} \mathrm{O}_{4} /$ reduced graphene oxide nanocomposites for novel bifunctional photocatalyst: one-pot synthesis, magnetically recyclable and enhanced photocatalytic property. J. Solid State Chem. 205, 171-176 (2013)

6. Montazeri, H., Amani, A., Shahverdi, H.R., Haratifar, E., Shahverdi, A.R.: Separation of the defect-free $\mathrm{Fe}_{3} \mathrm{O}_{4}$-Au core/shell fraction from magnetite-gold composite nanoparticles by an acid wash treatment. J. Nanostruct. Chem. 3, 25 (2013)

7. Zeynizadeh, B., Karimkoshteh, M.: Magnetic $\mathrm{Fe}_{3} \mathrm{O}_{4}$ nanoparticles as recovery catalyst for preparation of oximes under solventfree condition. J. Nanostruct. Chem. 3, 57 (2013)

8. Zhang, H., Zhu, G.: One-step hydrothermal synthesis of magnetic $\mathrm{Fe}_{3} \mathrm{O}_{4}$ nanoparticles immobilized on polyamide fabric. Appl. Surf. Sci. 258, 4952-4959 (2012)

9. Masteri-Farahani, M., Movassagh, J., Taghavi, F., Eghbali, P., Salimi, F.: Magnetite-polyoxometalate hybrid nanomaterials: synthesis and characterization. Chem. Eng. J. 184, 342-346 (2012)

10. Shi, J., Tong, L., Ren, X., Li, Q., Ding, H., Yang, H.: Bifunctional $\mathrm{Fe}_{3} \mathrm{O}_{4} @ \mathrm{C} / \mathrm{YVO}_{4}: \mathrm{Sm}^{3+}$ composites with the core-shell structure. Mater. Chem. Phys. 139, 73-78 (2013)

11. Xin, T., Ma, M., Zhang, H., Gu, J., Wang, S., Liu, M., Zhang, Q.: A facile approach for the synthesis of magnetic separable $\mathrm{Fe}_{3}$ $\mathrm{O}_{4} @ \mathrm{TiO}_{2}$, core-shell nanocomposites as highly recyclable photocatalysts. Appl. Surf. Sci. 288, 51-59 (2014)

12. Chen, S.H., Yin, Z., Luo, S.L., Au, C.T., Li, X.J.: Preparation of magnetic $\mathrm{Fe}_{3} \mathrm{O}_{4} / \mathrm{SiO}_{2} / \mathrm{Bi}_{2} \mathrm{WO}_{6}$ microspheres and their application in photocatalysis. Mater. Res. Bull. 48, 725-729 (2013)

13. Maleki, A.: $\mathrm{Fe}_{3} \mathrm{O}_{4} / \mathrm{SiO}_{2}$ nanoparticles: an efficient and magnetically recoverable nanocatalyst for the one-pot multicomponent synthesis of diazepines. Tetrahedron 68, 7827-7833 (2012)

14. Hu, H., Sun, J., Huang, G., Li, X., Dai, A., Yang, H., Yang, S.: Preparation of amino-functionalized magnetite nanoclusters by ring-opening polymerization and application for targeted magnetic resonance imaging. J. Mater. Sci. 48, 7686-7695 (2013)

15. Maleki, A.: One-pot multicomponent synthesis of diazepine derivatives using terminal alkynes in the presence of silica-supported superparamagnetic iron oxide nanoparticles. Tetrahedron Lett. 54, 2055-2059 (2013)

16. Chi, Y., Yuan, Q., Li, Y., Tu, J., Zhao, L., Li, N., Li, X.: Synthesis of $\mathrm{Fe}_{3} \mathrm{O}_{4} @ \mathrm{SiO}_{2}-\mathrm{Ag}$ magnetic nanocomposite based on small-sized and highly dispersed silver nanoparticles for catalytic reduction of 4-nitrophenol. J. Colloid Interface Sci. 383, 96-102 (2012)

17. Jiang, Y., Guo, C., Xia, H., Mahmood, I., Liu, C., Liu, H.: Magnetic nanoparticles supported ionic liquids for lipase immobilization: Enzyme activity in catalyzing esterification. J. Mol. Catal. B Enzym. 58, 103-109 (2009)

18. Zamani, F., Izadi, E.: Polyvinyl amine coated $\mathrm{Fe}_{3} \mathrm{O}_{4} @ \mathrm{SiO}_{2}$ magnetic microspheres for Knoevenagel condensation. Chin. J. Catal. 35, 21-27 (2014)

19. Singh, M., Ulbrich, P., Prokopec, V., Svoboda, P., Santava, E., Stepanek, F.: Vapour phase approach for iron oxide nanoparticle synthesis from solid precursors. J. Solid State Chem. 200, 150-156 (2013)

20. Tang, H., Zhou, W., Lu, A., Zhang, L.: Characterization of new sorbent constructed from $\mathrm{Fe}_{3} \mathrm{O}_{4} /$ chitin magnetic beads for the dynamic adsorption of $\mathrm{Cd}^{2+}$ ions. J. Mater. Sci. 49, 123-133 (2014)

21. Jalajerdi, R., Gholamian, F., Shafie, H., Moraveji, A., Ghanbari, D.: Thermal and magnetic characteristics of cellulose acetate$\mathrm{Fe}_{3} \mathrm{O}_{4}$. J. N. S. 2, 105-109 (2012)

22. Duan, J., Liu, R., Chen, T., Zhang, B., Liu, J.: Halloysite nanotube- $\mathrm{Fe}_{3} \mathrm{O}_{4}$ composite for removal of methyl violet from aqueous solutions. Desalination 293, 46-52 (2012)

23. Ali, S.D., Hussain, S.T., Gilani, S.R.: Synthesis, characterization and magnetic properties of carbon nanotubes decorated with magnetic $\mathrm{M}^{\mathrm{II}} \mathrm{Fe}_{2} \mathrm{O}_{4}$ nanoparticles. Appl. Surf. Sci. 271, 118-124 (2013)

24. Liu, J., Wang, L., Wang, J., Zhang, L.: Simple solvothermal synthesis of hydrophobic magnetic monodispersed $\mathrm{Fe}_{3} \mathrm{O}_{4}$ nanoparticles. Mater. Res. Bull. 48, 416-421 (2013)

25. Farghali, A.A., Bahgat, M., Elrouby, W.M.A., Khedr, M.H.: Decoration of multi-walled carbon nanotubes (MWCNTs) with different ferrite nanoparticles and its use as an adsorbent. J. Nanostruct. Chem. 3, 50 (2013) 